\begin{tabular}{|cc} 
Journal of & Publiser \\
\hline MangoementReview & $\begin{array}{l}\text { Graduate Program Universitas Galuh } \\
\text { Master Manajemen Studies Program } \\
\text { Co2017 }\end{array}$
\end{tabular}

\title{
IKLIM KERJA BERPENGRUH TERHADAP MOTIVASI DAN KINERJA PEGAWAI : STUDI PADA PERBANKAN DI WILAYAH KABUPATEN CIAMIS
}

\author{
Apri Budianto ${ }^{1}$ \\ ${ }^{1}$ Program Studi Manajemen Pascasarjana Universitas Galuh Ciamis \\ e-mail :apri.budianto@ymail.com
}

\author{
Article History : \\ Recieved 5 December 2016 \\ Recieved in revished form \\ 21 December 2016 \\ Acepted 5 Januari 2017 \\ Available offline 20 Januari 2017 \\ Available online 20 Januari 2017
}

Language Transcript :
Indonesia

Key Words :

Iklim Kerja

Motivasi

Kinerja Pegawai

\begin{abstract}
Artikel ini difokuskan pada pengaruh iklim kerja terhadap motivasi dan kinerja pegawai pada perbankan yang ada di wilayah Kabupaten Ciamis. Artikel ini dilatarbelakangi oleh menurunnya kinerj perbankan yang disebabkan oleh jeleknya iklim kerja dan motivas kerja pegawai yang berdampak pada menurunnya kinerja pegawai. Adapun rumusan masalah dalam artikel ini adalah iklim kerja di Perbankan Wilayah Ciamis, motivasi kerja di Perbankan Wilayah Ciamis, dan pengaruh iklim kerja terhadap motvasidan kinerja pegawai diPerbankan Wilayah Ciamis. Hipotesis kerja dalam artikel ini adalah : (1) Iklim Kerja berpengaruh positif terhadap kerja pegawai, (2) Motivasi Kerjaberpengaruh positif terhadap kinerja pegawai, dan (3) Motivasi kerja pegawai positifterhadapkinerja pegawai

Metode yang digunakan dalam pembuatan artikel ini dilakukan untuk mendapatkan gambaran tentang pengaruh iklim kerja terhadap motivasi dan kinerja pegawai pada Perbankan Wilayah Ciamis. Data dikumpulkan melalui teknik pengumpulan data di lapangan dengan menggunakan metode survey explanatory.

Hasil dari penelitian ini menunjukan bahwa Iklim kerja berpengaruh positif dan signifikan terhadap motivasi kerja pegawai. Artinya motivasi kerja pegawai dipengaruhi oleh iklim kerja di tempat ia bekerja, semakin baik iklim kerja di tempat mereka bekerja , maka akan semakin tinggi motivasi pegawainya, Iklim kerja berpengaruh positif dan signifikan terhadap kinerja pegawai. Artinya kinerja pegawai dipengaruhi oleh iklim kerja di tempat ia bekerja, semakin baik iklim kerja di tempat mereka bekerja, maka akan semakin tinggi kinerja pegawai, Motivasi kerja berpengaruh positif dan signifikan terhadap kinerja pegawai. Artinya kinerja pegawai dipengaruhi oleh motivasi kerja yang dimiliki oleh setiap pegawai, semakin tinggi motivasi kerja pegawai, maka akan semakin tinggi kinerja pegawai.
\end{abstract}

\section{PENDAHULUAN}

Sejak pertengahan 1997 (Sudjaya, 1998 :1) kinerja keuangan perbankan nasional menunjukkan kecenderungan terus menurun. Hal ini tercermin dari banyaknya bank yang mengalami kesulitan sehingga sejak bulan Oktober 1997 sampai bulan Mei 1998 Pemerintah melikuidasi 16 bank, membekukan operasi 14 bank dan mengambil alih manajemen 10 bank. Disamping itu terhadap 40 bank dilakukan pengawasan. Dampak yang ditimbulkan 
oleh kinerja perbankan tersebut

mengakibatkan turunnya tingkat kepercayaan dari masyarakat sehingga fungsi perbankan untuk menghimpun dana dari masyarakat menjadi terhambat, sehingga akan sangat memberikan peluang kepada bank-bank asing untuk mengambil kesempatan meraih dana dari masyarakat karena masyarakat akan merasa lebih aman jika dananya berada pada bank-bank asing.

Pada era globalisasi sekarang ini dunia perbankan dituntut untuk bekerja keras dalam melaksanakan fungsinya, karena yang menjadi persaingan perbankan saat ini bukan hanya bank pemerintah dan bank swasta milik bangsa Indonesia tetapi juga akan datang dari lembaga keuangan swasta milik negara lain. Maka manajemen para Manajer/Pimpinan Perbankan di Wilayah Kabupaten Ciamis dituntut untuk bekerja keras dalam mempertahankan kepercayaan masyarakat yaitu salah satunya dengan cara meningkatkan kinerja pegawai.

Dampak yang ditimbulkan oleh kinerja perbankan tersebut mengakibatkan turunnya tingkat kepercayaan dari masyarakat sehingga fungsi untuk menghimpun dana dan masyarakat menjadi terhambat, sehingga akan memberikan peluang kepada bank-bank asing untuk mengambil keputusan meraih dana dari masyarakat karena masyarakat akan merasa lebih aman jika dananya berada pada bankbank asing.

Eksistensi manusia di dunia ditandai dengan upaya yang tidak henti untuk menjadikannya sebagai manusia dimana setiap orang mempunyai bawaan yang disebut hak asasi, sebagai individu mempunyai privacy, sebagai masyarakat memiliki otonomi dan sebagai negara memiliki kedaulatan. Pemahaman ini berlangsung dalam dunia ciptaannya sendiri yang berbeda dengan dunia alamiah yakni kebudayaan.
Kebudayaan menduduki posisi sentral dalam saluran tatanan kehidupan manusia. Tak ada manusia yang dapat hidup di luar ruang lingkup kebudayaan. Kebudayaanlah yang memberi nilai dan makna pada hidup manusia. Seluruh bangunan hidup manusia dan masyarakat berdiri di atas landasan budaya.

Perubahan secara global telah memacu persaingan yang semakin tajam di berbagai sektor usaha terutama sektor perbankan baik di tingkat nasional maupun tingkat internasional. Untuk mendukung persaingan tersebut, aspek budaya kerja pegawai (pimpinan dan staf) serta pelayanan perlu mendapatkan perhatian secara khusus. Budaya kerja pegawai sangat bermanfaat dalam mendukung aktivitas organisasi perbankan terutama untuk membangun kembali citra positif perbankan yang sedang terpuruk. Melalui budaya kerja yang kuat diharapkan citra organisasi perbankan di mata masyarakat/nasabah baik eksternal maupun internal semakin positif dan pada akhirnya organisasi perbankan mendapat dukungan dari masyarakat sehingga mampu bersaing di tingkat nasional ataupun global.

Pandangan dan tanggapan terhadap perbankan nasional cukup besar, terutama mengenai kasus-kasus yang menunjukkan bagaimana aktivitas organisasi perbankan terganggu bahkan terhenti karena tekanan atau mendapat penolakan dari masyarakat. Dengan melalui perubahan sikap, perilaku, motivasi kerja dan iklim kerja yang baik, diharapkan kinerja pegawai semakin meningkat.

Perbankan sebagai organisasi/lembaga financial/keuangan dituntut untuk memiliki pelayanan yang baik, sehingga pada gilirannya mengarah pada pencapaian tujuan organisasi. Tujuan itu hanya dapat dicapai apabila pegawai memiliki disiplin, kemampuan baik berupa pengetahuan dan keterampilan, bermental baik, 
berpengabdian tangguh, jujur, tingginya tingkat inisiatif dan kreativitas serta memiliki motivasi/dorongan yang tinggi sehingga pekerjaan yang menjadi tanggung jawabnya dapat terlaksana dengan baik. Dengan kata lain pegawai bank harus memiliki sikap, perilaku, motivasi kerja dan iklim kerja yang baikuntuk dapat meningkatkan kinerja pegawai.

Efektifnya suatu organisasi lembaga keuangan/perbankan dapat dilihat dari seberapa besar tingkat pemenuhan kebutuhan kepada pegawai dan tingkat pencapaian tujuan organisasi perbankan serta tingkat kepuasan masyarakat melalui pelayanan, ini semua memerlukan kinerja pegawai yang profesional. Hal ini dapat ditandai dengan semakin kecilnya tingkat keluhan pegawai dan masyarakat terhadap pelayanan yang mereka terima.

Hal-hal yang tidak dapat dipungkiri selama ini bahwa pegawai bank kurang respon terhadap perkembangan dan tuntutan yang ada dalam masyarakat dan kurang transparan serta tuduhan klasik yang sulit dihilangkan adalah karyawan bank kurang berbudaya kerja, tidak memiliki kinerja yang baik, serta tidak dapat memberikan pelayanan yang baik kepada nasabah. Selain itu rendahnya kinerja pegawai disebabkan oleh cara pandang organisasi perbankan yang terlalu berorientasi kepada kegiatan dan pertanggungjawaban formal, sehingga lambat laun pekerjaan dalam organisasi menjadi kurang menarik dan kurang menggairahkan.

Perkembangan masyarakat yang semakin hari semakin dinamis dengan tingkat kehidupan dan pendidikan yang semakin baik merupakan proses pemberdayaan yang dialami masyarakat yang menurut perubahan posisi dan peran pegawai dari yang selama ini dilakukan ke arah yang lebih baik melalui pelayanan. Peran pegawai yang suka mengatur dan meminta dilayani harus diubah menjadi senang melayani masyarakat secara memuaskan dengan cara kerja yang realistik, pragmatik dan programik.

Perbankan harus dapat menciptakan kondisi keseimbangan antara tuntutan aktual masyarakat dan transparan dengan kemampuan untuk memenuhi tuntutan tersebut agar tujuannya tercapai. Tujuan itu hanya dapat dicapai apabila pegawai dapat menunjukkan sikap dan perilaku yang baik, motivasi yang tinggi, sertadidukung oleh iklim kerja yang sehat. Sikap yang demikian merupakan suatu keharusan untuk dijaga, apalagi eksesnya bisa merugikan masyarakat seperti lahirnya sikap arogansi yang berakibat kepercayaan diri yang berlebihan karena sikap perilaku itu merupakan cerminan budaya kerja pegawai.

Kinerja pegawai berhubungan erat dengan sikap dan perilaku yang dibentuk oleh suatu budaya yang dimiliki pegawai dalam organisasi yang disebabkan oleh tingkat kemampuan yang berkenaan dengan kecerdasan yang berbeda baik yang berupa bawaan sejak lahir maupun kecerdasan dalam menyerap informasi yang berkaitan dengan tingkat pendidikan dan pengalaman kerja. Ditambah lagi dengan tingkat kebutuhan yang berbeda yang berkaitan dengan kebutuhan fisik sampai pada tingkat aktualisasi diri, tingkat pengharapan sebagai rangkaian timbal balik dari tugas yang telah diselesaikan, tingkat pemahaman dalam lingkungan organisasi dan reaksi senang dan tidak senang terhadap pekerjaannya.

Sikap, perilaku, iklim kerja dan motivasi pegawaiyang demikian dipengaruhi oleh budaya kerja dalam suatu organisasi. Upaya-upaya yang dapat dilakukan dalam meningkatkan budaya kerja adalah pengembangan diri dan peningkatan diri pegawai. Pengembangan diri merupakan suatu proses pendidikan diri sendiri maupun yang diprogramkan oleh instansi perbankan, sedangkan peningkatan diri 
merupakan usaha untuk memperbaiki perilaku sesuai dengan nilai-nilai moral etika yang berlaku.

Istilah iklim merupakan kiasan (metafora). Kiasan adalah bentuk ucapan yang di dalamnya suatu ustilah atau frase yang jelas artinya diterapkan pada situasi yang berbeda dengan tujuan menyatakan suatu kemiripan, contohnya "tempat ini seperti kebun binatang". Meskipun perbandingannya figuratif, perbandingan tersebut memberi informasi mengenai isi, struktur, dan arti situasi baru tersebut. Seperti yang dinyatakan Sackman (1989 : 465) "Suatu kiasan dapat memberi gambaran yang gamblang pada tingkat kognitif, emosional, perilaku, dan menyatakan suatu bagian tertentu pada tingkatan tanpa menetapkan perilaku sebenarnya." ( R. Wayne Pace \& Don F. Faules dalam Deddy Mulyana, 2002 : 146 ).

Iklim Kerja memiliki dampak pengaruh yang besar terhadap motivasi kerja pegawai dan pada akhirnya berdampak pula pada peningkatan kinerja pegawai, karena iklim kerja merupakan salah satu faktor yang dapat mempengaruhi sikap dan perilaku manusia pada umumnya dan pegawai pada khususnya.

Dalam setiap organisasi sifat-sifat budaya kerja harus dapat dipahami sebagai suatu bagian penting dalam peningkatan kinerja. Sifat budaya kerja tidak hanya menunjukkan bagaimana kualitas kinerja pegawai, tetapi juga menunjukan bagaimana kualitas pelayanan. Pemahaman budaya kerja memberikan kesanggupan bagi pegawai baik secara individu maupun organisasi untuk memanfaatkan kemampuan dan keterampilannya.

Kinerja pegawai berhubungan erat dengan sikap, perilaku,iklim kerja dan motivasi kerjayang dimiliki pegawai dalam suatu organisasi. Sikap, perilaku, motivasi kerja dan iklim kerja merupakan suatu komitmen yang luas dalam upaya meningkatkan kinerja pegawai dengan proses kerja dan hasil kerja yang baik serta berkualitas. Triguno (1999 : 1) menyatakan bahwa :

Budaya kerja dan motivasi kerja sudah lama dikenal oleh umat manusia, namun belum disadari bahwa suatu keberhasilan kerja berakar pada nilai-nilai yang dimiliki melalui perilaku dan sikap yang menjadi kebiasaan pegawai. Nilai-nilai tersebut bermula dari adat kebiasaan, agama, norma dan kaidah yang menjadi keyakinannya sebagai kebiasaan dalam perilaku dan sikap kerja organisasi. Nilai-nilai yang telah menjadi kebiasaan dalam organisasi tersebut dinamakan budaya, dan mengingat hal ini dikaitkan dengan mutu atau kualitas kerja, maka dinamakan budaya kerja.

Motivasi didefinisikan sebagai semua kondisi yang memberi dorongan dari dalam diri seseorang yang digambarkan sebagai keinginan, kemauan, dorongan dan sebagainya. Motivasi merupakan keadaan dalam diri seseorang yang mengaktifkan atau menggerakan, maka dari pandangan seorang manajer / pimpinan seorang yang termotivasi akan :

- $\quad$ selalu bekerja keras

- $\quad$ selalu mempertahankan langkah kerja dengan keras

- memiliki perilaku yang dikendalikan sendiri ke arah sasaran-sasaran yang penting.

Motivasi kerja menurut Ernest J. Mc. Cormick (1985 : 268) menyatakan bahwa : "Work motivation is defined as conditions which influence the arousal, direction, and maintenance of behaviors relevant in work settings". Artinya motivasi kerja didefinisikan sebagai kondisi yang berpengaruh membangkitkan, mengarahkan dan memelihara perilaku yang berhubungan dengan lingkungan kerja.

Menurut pendapat Don Harvey and Robert Bruce (1996 : 140), Kinerja adalah "Performance may be defined as the 
journal of managementReview

ISSN-P : 2580-4138 ISSN-E 2579-812X http://jurnal.unigal.ac.id/index.php/managementreview Volume 1 Number 1 Page (1-11)

accomplishment of an employee or managers assigned duties and the outcomes produced on a apecified time period". Kinerja dapat diartikan sebagai keberhasilan pegawai atau manajer mengerjakan tugas dan menghasilkan suatu keluaran dalam waktu yang telah ditentukan. Disini dituntut kedisiplinan dan kemampuan pemimpin dalam memecahkan suatu masalah sehingga hasil yang didapatkan akan maksimal.

Selanjutnya masih menurut Don Harvey dan Robert Bruce (1996 : 140), pengukuran kinerja menggambarkan :

"performance appraisal review or evaluations refers to a systematic description and review of an individuals jobs performance".

Pendapat di atas dapat diartikan bahwa pengukuran kinerja digunakan untuk menggambarkan atau mengevaluasi suatu deskripsi dan gambaran sistematik dari kinerja seseorang. Untuk mengetahui kinerja seseorang harus teliti dan objektif sehingga diperlukan manajemen kinerja, sesuai dengan pendapat Don Harvey dan Robert Bruce (1996 : 140) bahwa "Performance management refers to the total system of gathering information, the riview and feedback to the individual, and storing information to improve organizational effectiveness".

Sejalan dengan pendapat di atas Werther dan Keith Davis (1996 : 341) berpendapat bahwa pengukuran kinerja adalah :

"Performance appraisal is the process by which organizations evaluate individual job performance ......... performance appraisal are about employee performance and accountability".

Pendapat di atas dapat diartikan bahwa manajemen kinerja merupakan total dari suatu kumpulan sistem informasi, gambaran dan umpan baliknya pada tiap individu, dan memasukkan informasi untuk memperbaiki efektivitas organisasi.

Sedangkan pengertian kinerja menurut Inpres Nomor 7/1999 adalah gambaran tingkat pencapaian pelaksanaan suatu kegiatan/program/kebijaksanaan dalam mewujudkan sasaran, tujuian, misi, dan visi organisasi.

Berdasarkan pengertian kinerja di atas, maka kinerja sama dengan :

- Performance

- Penampilan

- Penampilan cara-cara menghasilkan sesuatu dan hasil yang diperoleh

- Aktifitas kerja mencapai hasil

- Berkenaan dengan hasil yang dicapai

- Unjuk kerja, menghasilkan sesuatu

Pada kenyataannya bahwa iklim kerja yang terjadi di PT. Bank BRI Cabang Tasikmalaya sangat dominant mempengaruhi motivasi dan kinerja pegawai. Iklim kerja sangat dipengaruhi oleh adanya perputaran pegawai yang terlalu cepat dan adanya target yang harus dicapai, sehingga setiap pegawai berlomba secara individu untuk meningkatkan kinerjanya.

Masalah yang dapat dijawab melalui artikel ini adalah (i) iklim kerja di Perbankan Wilayah Ciamis (ii) motivasi kerja di Perbankan Wilayah Ciamis, dan pengaruh iklim kerja terhadap motvasidan kinerja pegawai diPerbankan Wilayah Ciamis.

Adapun hipotesis kerja dalam artikel ini adalah : (1) Iklim Kerja berpengaruh positif terhadap kerja pegawai, (2) Motivasi Kerjaberpengaruh positif terhadap kinerja pegawai, dan (3) Motivasi kerja pegawai positifterhadapkinerja pegawai.

\section{METOOLOGI}

Metode yang digunakan dalam pembuatan artikel ini dilakukan untuk mendapatkan gambaran tentang pengaruh iklim kerja 
terhadap motivasi dan kinerja pegawai pada

Perbankan Wilayah Ciamis. Data dikumpulkan melalui teknik pengumpulan data di lapangan dengan menggunakan metode survey explanatory.

Atas pertimbangan tujuan penelitian, maka penelitian ini menggunakan masalah verifikatif dan deskriptif. Sifat penelitian verifikatif pada dasarnya ingin menguji kebenaran dari suatu hipotesis yang dilaksanakan melalui pengumpulan data di lapangan. Mengingat sifat penelitian ini adalah deskriptif dan verifikatif yang dilaksanakan melalui pengumpulan data di lapangan, maka metode penelitian yang digunakan adalah metode deskriptive survey dan metode explanatory survey.

Tipe penelitian bersifat causalitas, karena akan diuji pengaruh sebab akibat antara variabel bebas dan tak bebas. Unit analisis dalam penelitian ini adalah individu, karena hanya masyarakat yang dijadikan responden. Time horizon dalam penelitian ini adalah crossectional, karena informasi dari sebagian populasi (sampel responden) dikumpulkan langsung di tempat kejadian secara empirik dengan tujuan untuk mengetahui pendapat dari sebagian populasi terhadap objek yang sedang diteliti. Jenis data yang dibutuhkan dalam penelitian ini adalah data primer dan data sekunder. Data primer berupa himpunan informasi yang diperoleh dalam survey dengan metode wawancara dan menggunakan kuesioner terstruktur.

Data sekunder didapat dengan menelaah data yang diperoleh dari masyarakat penerima pelayanan, mempelajari dokumen-dokumen, laporan penelitian, publikasi dan literatur lain yang mendukung penelitian.

Menurut Nasir (1999:99), "Desain penelitian adalah semua proses yang diperlukan dalam perencanaan dan pelaksanaan penelitian “. Dalam penelitian ini, desain penelitian yang digunakan adalah survei eksplanatori (explanatory survey). Sehubungan dengan hal tersebut, Rusidi (2003:38) menjabarkan lebih jauh bahwa:

Penelitian survey eksplanatori termasuk tipe penelitian theoritical untuk ilmuilmu non eksak. Eksplanatori artinya penjelasan atau hal-hal yang berkaitan dengan menjelaskan (explanating), baik menjelaskan peristiwa atau keadaan sekarang (explanation) maupun menjelaskan peristiwa atau keadaan yang akan datang (prediction). Menjelaskan itu menunjukkan penyebab dari peristiwa atau menunjukkan akibat dari adanya atau terjadinya peristiwa itu. Oleh karena itu metode penelitian semacam ini disebut pula penelitian sebab akibat (causality research).

Penelitian eksplanatori survey, sebagaimana yang dinyatakan Kerlinger dalam Sugiyono (1988:3) adalah :

Penelitian yang dilakukan pada populasi besar maupun kecil, tetapi data yang dipelajari adalah data dari sampel yang diambil dari populasi tersebut, sehingga dibutirkan kejadian-kejadian relatif, distribusi dan hubungan-hubungan antar variabel, sosiologis maupun psikologis.

Penelitian dilakukan dengan mengumpulkan data-data kualitatif, yang selanjutnya disajikan dalam bentuk angka (dikuantifikasikan) untuk diuji secara verifikatif sesuai dengan rancangan analisis data.

Table 1. Operasionalisasi Variabel

\begin{tabular}{|c|c|c|c|}
\hline Variabel & Konsep Variabel & Indikator & $\begin{array}{c}\text { No. } \\
\text { Butir } \\
\text { Angket }\end{array}$ \\
\hline 1 & 2 & 3 & 4 \\
\hline $\begin{array}{c}\text { Iklim } \\
\text { Kerja } \\
(\mathrm{X})\end{array}$ & $\begin{array}{l}\text { Merupakan suatu } \\
\text { keadaan/situasi yang } \\
\text { memberikan informasi } \\
\text { mengenai isi, struktur, } \\
\text { dan arti situasi baru yang } \\
\text { mempengaruhi suatu } \\
\text { proses penciptaan atau } \\
\text { pembentukan nilai baru } \\
\text { (tambah) pada suatu unit } \\
\text { sumber daya. }\end{array}$ & $\begin{array}{ll}\text { a. } & \begin{array}{l}\text { Peristiwa } \\
\text { komunikasi }\end{array} \\
\text { b. } & \begin{array}{l}\text { Perilaku } \\
\text { manusia }\end{array} \\
\text { c. } & \begin{array}{l}\text { Respon } \\
\text { pegawai }\end{array} \\
\text { terhadap } \\
\text { pegawai } \\
\text { lainnya } \\
\text { d. } \\
\text { Harapn- } \\
\text { harapan } \\
\text { e. Konflik antar } \\
\text { personal } \\
\text { f. Kesempatan } \\
\text { bagi } \\
\text { pertumbuhan }\end{array}$ & $1-12$ \\
\hline
\end{tabular}




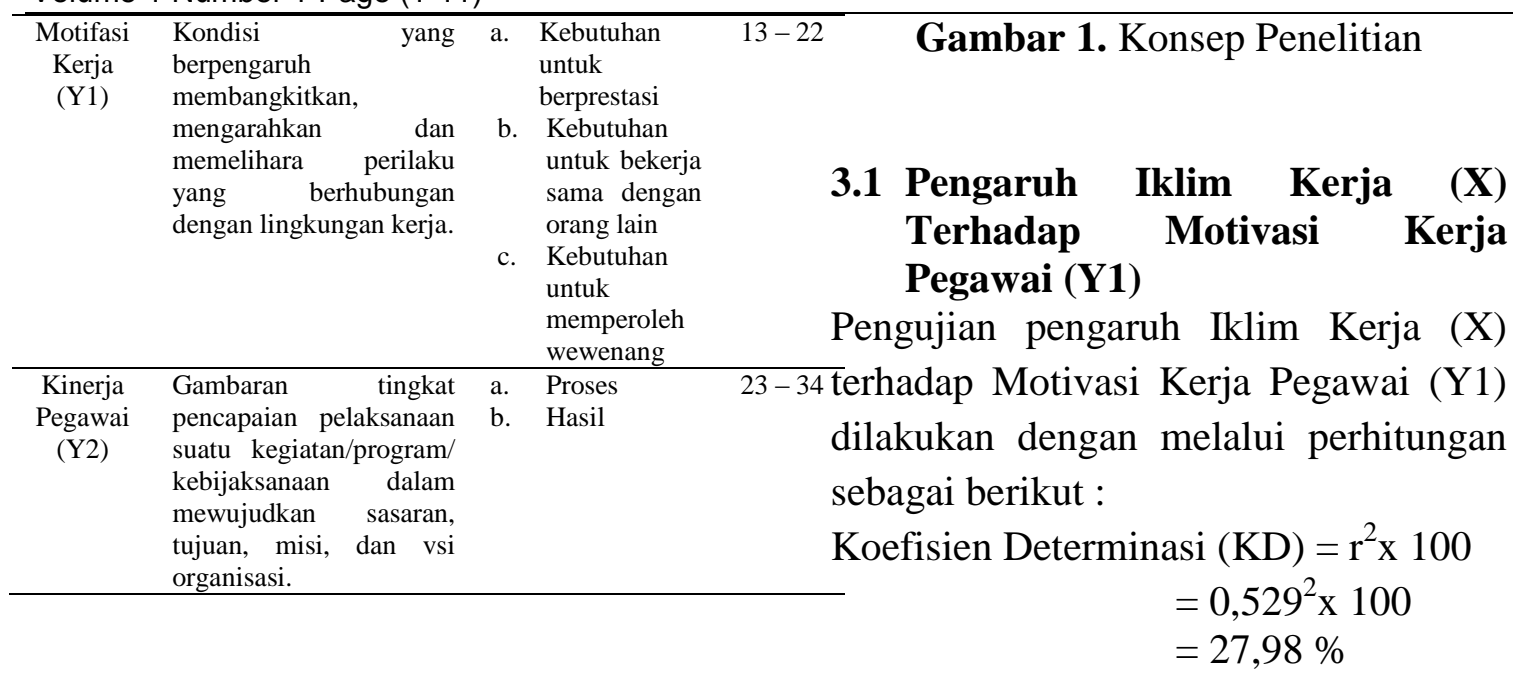

\section{HASIL DAN PEMBAHASAN}

Hasil analisis terhadap distribusi frekuensi jawaban responden melalui perhitungan skor dan prosentase sebagaimana yang telah dilakukan, masih belum dapat digunakan untuk menarik kesimpulan tentang pengaruh iklim kerja terhadap motivasi dan kinerja pegawai. Dengan kata lain hasil analisisnya belum menghasilkan kesimpulan yang valid, apakah hipotesis yang digunakan teruji dan dapat diterima atau tidak. Untuk mengetahui pengaruh langsung dan tidak langsung iklim kerja (X) terhadap Motivasi Kerja pegawai (Y1), pengaruh Iklim Kerja (X) terhadap Kinerja Pegawai (Y2), dan pengaruh Motivasi Kerja (Y1) terhadap Kinerja Pegawai (Y2). Untuk itu perlu dilakukan pengujian melalui susb-sub hipotesis dengan teknik analisis jalur. Berdasarkan hasil perhitungan analisis jalur diperoleh nilai koefisien korelasi jalur sebagaimana gambar ini :

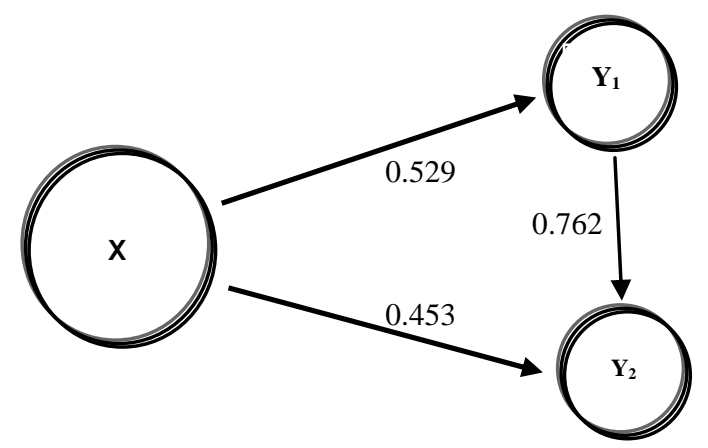

Jadi Motivasi Kerja pegawai dipengaruhi oleh Iklim Kerja sebesar 27,98\%. Artinya bahwa Motivasi Kerja pegawai hanya dipengaruhi sebagian kecil Iklim Kerja yaitu sebesar 27,98\%.

Sedangkan untuk menguji hipotesis digunakan uji t. Untuk menguji apakah hipotesis diterima atau tidak digunakan rumus sebagai berikut :

$$
\mathrm{t}=\frac{\mathrm{rs}}{\sqrt{\frac{1-\mathrm{r}^{2}}{\mathrm{n}-2}}}
$$

Kriteria Pengujian :

- Tolak $H_{o}$ jika $t_{\text {hitung }}>t_{\text {tabel }}$, artinya koefisien korelasi signifikan dan pengaruh dari Iklim Kerja terhadap Motivasi Kerja

- Tolak $H_{o}$ jika $t_{\text {hitung }}<t_{\text {tabel }}$, artinya koefisien korelasi tidak signifikan dan tidak ada pengaruh dari iklim kerja terhadap motivasi kerja.

Dengan koefisien korelasi ( r ) 0,529, maka besarnya $t_{\text {hitung }}$ adalah :

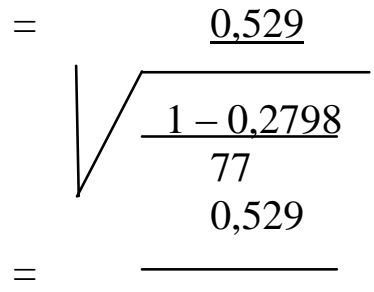




$$
\begin{array}{r}
0,095 \\
=\quad 5.568
\end{array}
$$

Karena dalam daftar $t_{\text {tabel }}$ tidak ada angka 79, maka penulis menghitung

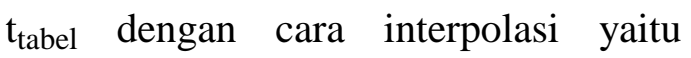
sebagai berikut :

$$
\mathrm{a}: \mathrm{b}=\mathrm{c}: \mathrm{d}
$$

$\left(n-t_{\text {tabel }}\right.$ awal $): t_{\text {tabel }}$ akhir $-t_{\text {tabel }}$ awal $=\left(X-t_{\text {tabel }}\right.$ awal $)$; $\mathrm{t}_{\text {tabel }}$ akhir $-\mathrm{t}_{\text {tabel }}$ awal

$77-60: 120-60=(X-1,6707):$

$1,6577-1,6707$

$17: 60=X-1,6707:-0,013$

$60 X-60(1,6707)=17(-0,013)$

$60 X-100,242=-0,221$

$60 X=100,242-0,221$

$60 X=100,021$

$\mathrm{X}=1,667$

Dengan demikian maka $t_{\text {hitung }}>t_{\text {tabel }}$ yaitu 5,568> 1,667. Maka hipotesis nol $\left(\mathrm{H}_{\mathrm{o}}\right)$ ditolak. Artinya iklim kerja berpengaruh positih terhadap motivasi kerja. Sehingga hipotesis yang pertama dapat diterima dan teruji kebenarannya.

\subsection{Pengaruh Iklim Kerja (X) Terhadap Kinerja Pegawai (Y2)}

Pengujian pengaruh Iklim Kerja (X) terhadap Kinerja Pegawai (Y2) dilakukan dengan melalui perhitungan sebagai berikut :

Koefisien Determinasi $(\mathrm{KD})=\mathrm{r}^{2} \mathrm{x} 100$

$$
\begin{aligned}
& =0,453^{2} \times 100 \\
& =24,60 \%
\end{aligned}
$$

Jadi kinerja pegawai dipengaruhi oleh Iklim Kerja sebesar 24,60\%. Artinya bahwa kinerja pegawai hanya dipengaruhi sebagian kecil Iklim Kerja yaitu sebesar 24,60\%.

Sedangkan untuk menguji hipotesis digunakan uji t.

Kriteria Pengujian :
- Tolak $\mathrm{H}_{\mathrm{o}}$ jika $\mathrm{t}_{\text {hitung }}>\mathrm{t}_{\text {tabel }}$, artinya koefisien korelasi signifikan dan pengaruh dari Iklim Kerja terhadap Kinerja Pegawai

- Tolak $\mathrm{H}_{\mathrm{o}}$ jika $\mathrm{t}_{\text {hitung }}<\mathrm{t}_{\text {tabel}}$, artinya koefisien korelasi tidak signifikan dan tidak ada pengaruh dari iklim kerja terhadap kinerja pegawai.

Dengan koefisien korelasi ( $r$ ) 0,453, maka besarnya $t_{\text {hitung }}$ adalah :

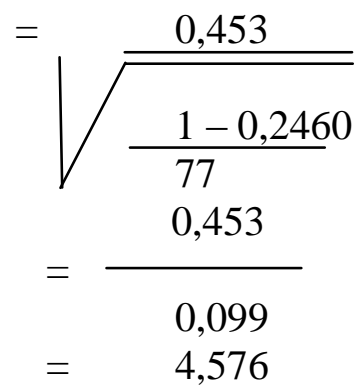

Karena dalam daftar $t_{\text {tabel }}$ tidak ada angka 79, maka penulis menghitung $t_{\text {tabel }}$ dengan cara interpolasi yaitu sebagai berikut :

$$
a: b=c: d
$$

$\left(n-t_{\text {tabel }}\right.$ awal $): t_{\text {tabel }}$ akhir $-t_{\text {tabel }}$ awal $=\left(X-t_{\text {tabel }}\right.$ awal $) ; t_{\text {tabel }}$ akhir $-\mathrm{t}_{\text {tabel }}$ awal

$77-60: 120-60=(X-1,6707):$ $1,6577-1,6707$

$17: 60=X-1,6707:-0,013$

$60 X-60(1,6707)=17(-0,013)$

$60 X-100,242=-0,221$

$60 X=100,242-0,221$

$60 X=100,021$

$\mathrm{X}=1,667$

Dengan demikian maka $t_{\text {hitung }}>t_{\text {tabel }}$ yaitu 4,576> 1,667. Maka hipotesis nol $\left(\mathrm{H}_{\mathrm{o}}\right)$ ditolak. Artinya iklim kerja berpengaruh positih terhadap kinerja pegawai. Sehingga hipotesis yang kedua dapat diterima dan teruji kebenarannya.

\subsection{Pengaruh Motivasi Kerja Pegawai (Y1) terhadap Kinerja Pegawai (Y2)}


Pengujian pengaruh motivasi kerja (Y1) terhadap Kinerja Pegawai (Y2) dilakukan dengan melalui perhitungan sebagai berikut :

Koefisien Determinasi $(\mathrm{KD})=\mathrm{r}^{2} \mathrm{x} 100$

$$
\begin{aligned}
& =0,762^{2} \times 100 \\
& =58,06 \%
\end{aligned}
$$

Jadi kinerja pegawai dipengaruhi oleh Motivasi Kerja sebesar 58,06\%. Artinya bahwa kinerja pegawai hanya dipengaruhi sebagian kecil Motivasi Kerja yaitu sebesar $58,06 \%$.

Sedangkan untuk menguji hipotesis digunakan uji t.

Kriteria Pengujian :

- Tolak $H_{o}$ jika $t_{\text {hitung }}>t_{\text {tabel }}$, artinya koefisien korelasi positif dan pengaruh dari Motivasi Kerja terhadap Kinerja Pegawai

- Tolak $H_{o}$ jika $t_{\text {hitung }}<t_{\text {tabel, }}$ artinya koefisien korelasi tidak positif dan tidak ada pengaruh dari motivasi kerja terhadap kinerja pegawai.

Dengan koefisien korelasi ( r ) 0,762, maka besarnya $t_{\text {hitung }}$ adalah

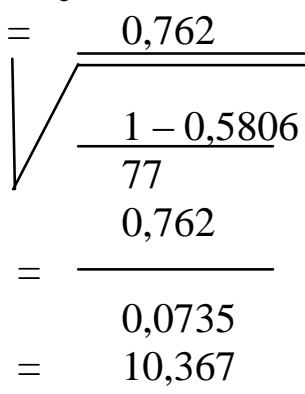

Karena dalam daftar $t_{\text {tabel }}$ tidak ada angka 79, maka penulis menghitung

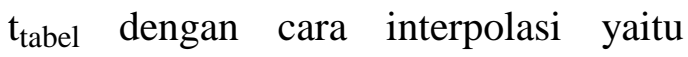
sebagai berikut :

$$
a: b=c: d
$$

$\left(\mathrm{n}-\mathrm{t}_{\mathrm{tabel}}\right.$ awal $): \mathrm{t}_{\mathrm{tabel}}$ akhir $-\mathrm{t}_{\mathrm{abbe}}$ awal $=\left(\mathrm{X}-\mathrm{t}_{\mathrm{tabel}}\right.$ awal $)$; $t_{\text {tabel }}$ akhir $-t_{\text {tabel }}$ awal

$77-60: 120-60=(X-1,6707):$

$1,6577-1,6707$

$17: 60=X-1,6707:-0,013$

$60 X-60(1,6707)=17(-0,013)$

$60 X-100,242=-0,221$

$60 X=100,242-0,221$

$60 X=100,021$
$X=1,667$

Dengan demikian maka $t_{\text {hitung }}>t_{\text {tabel }}$ yaitu 10,367>1,667. Maka hipotesis nol $\left(\mathrm{H}_{\mathrm{o}}\right)$ ditolak. Artinya Motivasi Kerja berpengaruh positih terhadap Kinerja Pegawai. Sehingga hipotesis yang ketiga dapat diterima dan teruji kebenarannya.

Secara teoritis bahwa Iklim Kerja berpengaruh terhadap Motivasi Kerja sesuai dengan pendapat para ahli. Selain itu Iklim Kerja berpengaruh terhadap Kinerja Pegawai. Hal ini dibuktikan dengan pendapat para ahli. Sedangkan Kinerja Pegawai sangat dipengaruhi oleh Motivasi Kerja Pegawai sesuai dengan kajian dari para ahli yang menyatakan bahwa Kinerja Pegawai sangat dipengaruhi oleh Motivasi Kerja Pegawai.

Untuk membuktikan dan membandingkan antara kajian teoritis dan empiris, maka penulis uji dengan tiga hipotesis yang penulis ajukan yaitu

\section{a. Hipotesis 1}

Pengaruh yang positif dari iklim kerja terhadap motivasi kerja pegawai.

- Tolak $\mathrm{H}_{\mathrm{o}}$ jika $\mathrm{t}_{\text {hitung }}>\mathrm{t}_{\text {tabel}}$, artinya koefisien korelasi positif dan pengaruh dari Iklim Kerja terhadap Motivasi Kerja

- Tolak $\mathrm{H}_{\mathrm{o}}$ jika $\mathrm{t}_{\text {hitung }}<\mathrm{t}_{\text {tabel }}$, artinya koefisien korelasi tidak positif dan tidak ada pengaruh dari iklim kerja terhadap motivasi kerja.

Dengan berdasarkan pada perhitungan di atas diperoleh $t_{\text {hitung }}>t_{\text {tabel }}$, maka dengan demikian $\mathrm{H}_{1}$ diterima dan $\mathrm{H}_{\mathrm{o}}$ 
ditolak, berarti hasil penelitian menunjukan adanya pengaruh yang positif dan signifikan antara varibel $\mathrm{X}$ (Iklim Kerja) terhadap Motivasi Kerja Pegawai (Y1).

\section{b. Hipotesis 2}

Pengaruh yang positif dari iklim kerja terhadap kinerja pegawai.

- Tolak $H_{0}$ jika $t_{\text {hitung }}>t_{\text {tabel }}$, artinya koefisien korelasi positif dan pengaruh dari Iklim Kerja terhadap Kinerja Pegawai

- Tolak $H_{o}$ jika $t_{\text {hitung }}<t_{\text {tabel }}$, artinya koefisien korelasi tidak positif dan tidak ada pengaruh dari iklim kerja terhadap kinerja pegawai.

Dengan berdasarkan pada perhitungan di atas diperoleh $t_{\text {hitung }}>t_{\text {tabel }}$, maka dengan demikian $\mathrm{H}_{1}$ diterima dan $\mathrm{H}_{\mathrm{o}}$ ditolak, berarti hasil penelitian menunjukan adanya pengaruh yang positif dan signifikan antara varibel $\mathrm{X}$ (Iklim Kerja) terhadap Kinerja Pegawai (Y2).

\section{c. Hipotesis 3}

Pengaruh yang positif dari motivasi kerja pegawai terhadap kinerja pegawai.

- Tolak $H_{o}$ jika $t_{\text {hitung }}>t_{\text {tabel }}$, artinya koefisien korelasi positif dan pengaruh dari Motivasi Kerja terhadap Kinerja Pegawai

- Tolak $H_{o}$ jika $t_{\text {hitung }}<t_{\text {tabel }}$, artinya koefisien korelasi tidak positif dan tidak ada pengaruh dari motivasi kerja terhadap kinerja pegawai.

Dengan berdasarkan pada perhitungan di atas diperoleh $t_{\text {hitung }}>t_{\text {tabel }}$, maka dengan demikian $\mathrm{H}_{1}$ diterima dan $\mathrm{H}_{\mathrm{O}}$ ditolak, berarti hasil penelitian menunjukan adanya pengaruh yang positif dan signifikan antara varibel Y1 (Motivasi Kerja Pegawai) terhadap Kinerja Pegawai (Y2).

\section{SIMPULAN}

Berdasarkan hasil pengujian sub-sub hipotesis dapat disimpulkan bahwa :

1. Iklim kerja berpengaruh positif dan signifikan terhadap motivasi kerja pegawai. Artinya motivasi kerja pegawai dipengaruhi oleh iklim kerja di tempat ia bekerja, semakin baik iklim kerja di tempat mereka bekerja , maka akan semakin tinggi motivasi pegawainya. Dengan demikian hipotesis pertama diterima.

2. Iklim kerja berpengaruh positif dan signifikan terhadap kinerja pegawai. Artinya kinerja pegawai dipengaruhi oleh iklim kerja di tempat ia bekerja, semakin baik iklim kerja di tempat mereka bekerja , maka akan semakin tinggi kinerja pegawai. Dengan demikian hipotesis kedua diterima.

3. Motivasi kerja berpengaruh positif dan signifikan terhadap kinerja pegawai. Artinya kinerja pegawai dipengaruhi oleh motivasi kerja yang dimiliki oleh setiap pegawai, semakin tinggi motivasi kerja pegawai , maka akan semakin tinggi kinerja pegawai. Dengan demikian hipotesis ketiga diterima.

\section{DAFTAR PUSTAKA}

Conover, WJ., 1980, Praktical Non Parametric, Statistics 2 ed., New York Chichester, Singapore. 
Deddy Mulyadi, 2002, Komunikasi Organisai Strategi Meningkatkan Kinerja Perusahaan, Penerbit PT. Remaja Rosadakarya, Bandung.

Elly Sunandy, 2003, Perilaku Organisasi, Penerbit Salemba Empat, Jakarta.

Gomes, Faustino Cardos, 1990, Manajemen Sumber Daya Manusia, Andi Offset, Yogyakarta

Hasibuan, Melayu, SP, 1990, Manajemen Sumber Daya Manusia, CV. Haji Masagung, Jakarta.

Hasibuan, S.P. Malayu, 1997, Manajemen Sumber Daya Manusia Dasar dan Kunci Keberhasilan, Cetakan Kembali, Penerbit PT. Toko Gunung Agung, Jakarta

Heady, Farrel, 1998, Public Administration, Comparative Study, Prentice Hall, New York.

Hidayat, 1989, Konsep Dasar Pengertian Produktivitas Kerja serta Interprestasi Hasil Pengukurannya, prisma LP3ES, Jakarta.

Kerlinger, Fred N. dan Elazar Padhazur, 1987, Foundation of Behavioral Research Jurnal Wacana Kinerja Nomor 4 Tahun , LAN Perwakilan Jawa Barat.

Lovelock, Christopher, 1994, Product Plus : How Product and Service, Competitive Advantage, Mc. Grow Inc., Singapore.

Ndraha Taliziduhu, 1989, Konsep Administrasi dan Administrasi di Indonesia, LP3ES, Jakarta.

Nunuk Aduarni, 1996, Organisasi, Bina Aksara, Jakarta

Prabu Anwar Mangkunegara, 2000, Manajemen Sumber Daya Manusia, Remaja Rosda Karya, Bandung

Sedarmayanti, 2001, Sumber Daya Manusia dan Produktivitas Kerja, $\mathrm{CV}$. Mandar Maju, Bandung
Siegel Sidney, 1992, Statistika Non Parametrik untuk Ilmu-Ilmu Sosial, Gramedia, Jakarta

Singarimbun, Masri dan Sofyan Effendi, 1995 Metode Penelitian Survey, LP3ES, Jakarta.

Sitepu, Nirwan SK., 1994, Path Analysis, UPS Universitas Padjajaran, Bandung.

Sondang P. Siagian, 1999, Manajemen Sumber Daya Manusia, Bumi Aksara, Jakarta. 